уровня сервиса и качества оказываемых услуг. Изучение вопросов появления новых и развития имеющихся туристских маршрутов для категории путешественников «55+» должно стать предметом постоянного внимания со стороны туристских фирм и организаций Алтайского края.

Список литературы

1. Илькевич С. В. Перспективы туризма старшего возраста в контексте пенсионной реформы в России. Стратегические решения и риск-менеджмент. 2018. № 4. С. 66-71.
2. Alen E., Nicolau J. L., Losada N., Determinant factors of senior tourists' length of stay. Annals of Tourism Research. 2014. Vol. 49. P. 19-32.

3. Досуг граждан старшего поколения. URL: $\quad$ http://government.ru/docs/all/105372/? page $=2(12.03 .21)$.

4. Age Platform Europe. Global certification scheme senior-friendly hotels. URL: https:/www.age-platform.eu/good-practice/globalcertification-scheme-senior-friendly-hotels-friendly (12.03.21).

УДК 069(571.53):39+291.71: 351.852.14

DOI: $10.32340 / 2514-772 X-2021-1-59-62$

В. В. Тихонов,

кандидат культурологии

Архитектурно-этнографический музей «Тальцы» (Иркутск, Россия) talci@irk.ru

\title{
АУТЕНТИЧНАЯ РЕКОНСТРУКЦИЯ БУРЯТСКОГО МИССИОНЕРСКОГО СТАНА В МУЗЕЕ «ТАЛЬЦЫ» КАК ОДНОГО ИЗ ОБРАЗОВАТЕЛЬНЫХ УЧРЕЖДЕНИЙ ПРОШЛОГО
}

Аннотация: в рамках обеспечения сохранения исторической памяти рассматривается перспектива аутентичного воссоздания на основе элементов оригиналов и новоделов бурятского православного миссионерского стана в экспозиционном пространстве Архитектурно-этнографического музея «Тальцы». Анализируются предпосылки возникновения бурятских православных миссионерских станов, хронология их создания, инфраструктура наполнения и их роль в системе образовательных процессов в регионе, в особенности по отношению к коренной народности - бурятам. Предлагается к рассмотрению широкой общественности уже реализуемая концепция обобщенной модели бурятского православного миссионерского стана конца XIX в. в музейном пространстве.

Ключевые слова: миссионерский стан, улус-зимник, юрта, буряты, инородиы, экспозиция, музеефикачия.

Освоение территории Предбайкалья русскими первопроходцами началось со второй четверти XVII в. Вместе с казаками в движении на восток участвовало и православное духовенство. В первом Илимском остроге (1647 г.) уже стояла изба черного монаха [1, с. 38]. В 1681 г. православная миссия в Предбайкалье состояла из 12 монахов со старшим у них игуменом Феодосием. К 1851 г. ситуация с православием в Предбайкалье сложилась таким образом, что доля православного населения среди коренных жителей, в основном предбайкальских (западных) бурят, составляла только 68,4 \% [2, с. 104], что было самым низким показателем среди соседних регионов. Остальные проценты составляли шаманисты и отчасти ламаисты.

Середина XIX в. в регионе обозначилась тем, что миссионерская деятельность среди коренного населения усилилась. Главными миссионерами стали православные священники и в значительной меньшей степени представители ламаистской конфессии, для которых в их деятельности властями создавались искусственные препятствия. С целью интенсификации православной миссионерской деятельности в 1861 г. была учреждена Иркутская православная миссия. Благодаря ей уже в 1863 г. появилось пять миссионеров, преподававших среди инородцев (бурят) [3, с. 196]. Одним из них стал инородец протоирей Николай Нилович Доржаев - западный бурят, перешедший в православие из ламаистов. Именно с 60-х гг. XIX в. в Предбайкалье появляются первые миссионерские станы среди инородцев. К началу Первой мировой войны их было в регионе 26.

Православные миссионерские станы располагались непосредственно в бурятских улусах или, редко, вблизи от них, не далее 4 км. Это объяснялось тем, что миссионер часто отлучался по делам епархии или ездил по улусам с миссионер- 
ской миссией, и из-за опасности воровства надолго оставлять стан ему не рекомендовалось.

Православные миссионерские станы обслуживали от 15 до 43 улусов с приписной численностью населения от 3 до 12 тыс. человек [4, c. 196]. Расстояние от улусов до станов обычно не превышало 80 км, хотя в северных районах были улусы, удаленные от стана на 330 км. Основная масса станов располагалась в местах проживания бурят в Иркутском, Верхоленском и Балаганском уездах. Официальные источники утверждали, что в 1910 г. число крещеных в православие в Иркутской губернии составляло $85,5 \%$ [5, с. 234]. При этом исследования П. Е. Кулакова показывали, что на рубеже XIXXX вв. обращенных в православие западных бурят было всего около $35 \%$ [6, с. 120] и то значительное количество из них являлось двоеверцами. Ситуация с двоеверцами сложилось потому, что многие инородцы принимали православие формально, часто в рамках меркантильных интересов. При крещении инородцам выдавали подарки. Подарками были медные крестики, крестильные рубахи или штаны, халаты, а также денежные подарки - чаще всего им давали по 3 рубля [2, с. 58]. В качестве уникальных случаев отмечались подарки, выдаваемые при крещении купцом 2-й гильдии Карлом Карловичем Сапожниковым - по 35 руб. на душу. Для того времени это были большие деньги [7]. Подарками для крестившихся были также иконы, а после крещения их приглашали на трапезу к богато накрытым столам, расположенным рядом с местом крещения [8, с. 129-130]. Ну кто-же от всего этого откажется!

По той же официальной статистике, на 1911 г. шаманистами среди западных бурят считалось около 50 тыс., а среди иных инородцев тунгусов (эвенков) и карагасов (тофов) - около 2 тыс. человек. Незначительным было число представителей ламаистской конфессии: от 5 до $10 \%$ коренного населения [5, с. 242].

Под православные миссионерские станы, как правило, выбирали места рядом с инородческими (Степными) думами в больших улусах [8, с. 104; 9, с. 56]. Одновременно православные миссионерские станы старались обустраивать у какого-либо проточного водоема, для удобства крещения [3, с. 196]. В основе православного миссионерского стана всегда была церковь, которая со второй половины XIX в. строилась уже по типовым (рекомендованным) проектам. Все церкви миссионерских станов были деревянными. В инфраструктуру миссионерских станов входили и церковно-приходские школы. На 1915 г. из 26 имевшихся в регионе православ- ных миссионерских станов школы имели 11, в остальных ученики обучались в домах миссионеров (когда было мало учеников) [10, с. 183]. В среднем в школах училось от 10 до 30 учеников, как инородцев, так и русских. Основным преподавателем в школе был священник. А когда учеников было много, священник нанимал для обучения учителя. Священник учил Закону Божьему, читать, писать и считать. Учитель в дополнение к отмеченным дисциплинам мог преподавать и другие предметы. К примеру, историю, географию, даже музыку.

Школы отличались размерами и архитектурой. Архитектурное оформление стремились приблизить к этническим мотивам коренного населения. Поскольку школы находились в относительной удаленности от основных центров региона, это сказывалось и на обеспечении учебного процесса школьным инвентарем. Если книг для чтения хватало, то тетрадями практически не пользовались, письму учились на школьной доске или на грифельной. Счет осваивали на счетах или другими способами. Закон Божий учили по церковным книгам или по наглядной (лубковой) агитации. Двуклассное образование в таких школах получали за четыре года обучения.

Стремление привить детям инородцев светское образование постепенно отталкивало их от веры предков - шаманизма - и в большей степени укореняло православную веру. Этому же способствовало приобщение местного инородческого населения, взрослых и детей, к лечению не у шаманов и лам, а у фельдшеров или врачей. Для этого в православных миссионерских станах, где это было возможно, создавались примитивные фельдшерские пункты и аптеки. Чаще это делалось в доме миссионера, где содержался необходимый набор лекарств, и куда по определенным дням приезжал фельдшер. Необходимо отметить, что на первых порах создания православных миссионерских станов для расселения миссионеров могли арендоваться или покупаться пустующие в улусах (поселках) дома местных жителей. При устройстве православных миссионерских станов для создания превосходства европейского образа ведения хозяйства над степным-кочевым-скотоводческим рекомендовалось формировать усадьбу с домом по наилучшим городским типам с образцовым огородом. В связи с удаленностью миссионерских станов от некоторых улусов на многие десятки верст обучение детей производилось по принципу интернатов, устраивавшихся в пустующих или арендованных домах улусов-зимников, в состав которых входил миссионерский стан. 
Иногда для того, чтобы детей из удаленных улусов навещали родители, в миссионерских станах в зависимости от числа обучавшихся ставили одну или несколько гостевых юрт [11, с. 24]. Отмечен случай, когда в Боханском православном миссионерском стане купец К. К. Сапожников построил в 1877 г. на свои средства вместе школы училище. Училище разделялось на две половины - для девочек и мальчиков: «Каждое утро все ученики собирались в одной комнате и пели молитву. Затем девочки уходили в свое женское отделение, а мальчики оставались в своем» [9, с. 42]. В основном, среди обучавшихся в миссионерских школах существенно преобладали мальчики, иногда были полностью мальчишеские школы. В период массового крещения, а это происходило летом, когда ученики были на каникулах, в юртахобщежитиях могли останавливаться на ночлег новокрещенные, приезжавшие из дальних улусов.

По состоянию на начало XX века, штат православных миссионерских станов состоял в основном из священника и псаломщика [2, с. 2]. Для обращения инородцев в православную веру их требовалось крестить. Если младенцев крестили в купелях (небольших емкостях, наполненных водой) в храмах, то крещение взрослых проводилось в теплое время на ближайших водоемах, где на момент крещения, особенно массового, строили крещальни [12, с. 322]. Крещальни делали «особо для мужчин и особо для женщин» $[13$, с. 65]. Крещальни предусматривали пологий, без кустарника, сход в реку в том месте, где можно было окунуться с головой. Окунались в воду три раза. Иногда на спуске устраивали мостики, а место, где окунались женщины, закрывали полотняной тканью. Количество крестившихся было различным. К примеру, при массовом крещении в Идинском ведомстве в реке Ида в 1867 г. крестилось сразу 120 человек [14, с. 221-222]. В 1908 г. для выполнения обряда крещения в храме даже были выпущены «Практические советы и разъяснения по вопросам миссионерской практики» [15].

Для формирования экспозиционного пространства музейного комплекса регионального масштаба Архитектурно-этнографического музея «Тальцы» впервые в Российской Федерации было проведено детальное историко-культурное зонирование музеефицируемой территории (Иркутской области) по этно-географоэкономико-хозяйственному принципу с выделением основных этномаркирующих составляющих, по которым можно характеризовать мате- риальную культуру этносов и этнических групп в зависимости от территории проживания, специфики экономики, хозяйственной деятельности и др. По результатам зонирования на территории Иркутской области было выделено десять историко-культурных зон, девять из которых предлагалось сформировать в экспозиционном пространстве музея «Тальцы» [16]. В составе Бурятской экспозиционной зоны было предложено воссоздать экспозицию «Бурятский православный миссионерский стан» [16, с. 193]. Учитывая то, что в настоящее время на территории региона не осталось ни одного православного миссионерского стана, а отдельные сохранившиеся объекты растащены по разным местам (часть их попала в колхозную инфраструктуру, а в период ликвидации неперспективных деревень в 60 -е гг. XX в. - в частные усадьбы), было принято решение воссоздать в музее обобщенный образ православного миссионерского стана за счет переноса в музейное пространство сохранившихся до нашего времени объектов. Для размещения экспозиции бурятского миссионерского стана в музее «Тальцы» выбран подходящий участок ландшафта на берегу ручья, где в настоящее время заканчивается планировка территории. На территорию музея под экспозицию миссионерского стана уже вывезено здание Кутуликского миссионерского училища, которое находится пока на хранении во временной сборке. В 2020 г. от мецената получено другое здание - дом священника, и музей готовится к его вывозке на свою территорию. Кроме того, подобрана деревянная восьмистенная юрта, а также решается вопрос с выбором церкви. Здесь проблема в том, что в регионе все церкви поставлены на учет как объекты историко-культурного наследия и по закону подлежат реставрации на историческом месте. Тем не менее, вопрос решается, хотя возможен и совсем простой вариант выполнения миссионерской церкви в новоделе по аналогу. Последнее довольно часто применяется многими музеями, в особенности при отсутствии оригиналов. Таким образом, перспектива реального аутентичного воссоздания образа православного миссионерского стана в музейном пространстве Архитектурно-этнографического музея «Тальцы» вполне реальна. При этом следует отметить, что материальные носители, размещенные в музейном экспозиционном пространстве - это, по сути, гарантированная государством форма сохранения исторической памяти нашего народа, в свою очередь являющаяся частью исторического наследия человеческой цивилизации. 
Список литературы

1. Государственный архив Иркутской области. Ф. 50. ОП. 1. Д. 9100. Отчет о состоянии Залогского миссионерского стана за 1911 г.

2. Любимов П. П. Религии и вероисповедный населения Азиатская Россия// Азиатская Россия. Т.1. Люди и порядки за Уралом. СанктПетербург, 1914. С. 200-242.

3. Дулов А. В., Санников А. П. Православная церковь в Восточной Сибири в XVII - начале XX веков. Ч. 2. Иркутск, 2006. 323 с.

4. Елисеев Е. свящ., миссионер. Практические советы и разъяснения по вопросам миссионерской практики // Тобольские епархиальные ведомости. 1908. № 23. С. 458-461.

5.Иркутские епархиальные ведомости. 1868. № 25.

6. Иркутские епархиальные ведомости. 1870. № 40 .

7. Иркутские епархиальные ведомости. 1895. № 9 .

8. Иркутские епархиальные ведомости. 1915. № 9.

9. Кулаков П. Е. Буряты Иркутской губернии // Известия ВСОИРГО. Иркутск, 1895. Т. 26. Вып. 4/5. С. 118-166.

10. Тихонов B. B. Историко-культурное наследие Предбайкалья и перспектива его сохранения методом этнографических музейных комплексов под открытым небом. Иркутск, 2013. 364 c.

11. Тихонов В. В. Перспективы музеефикации элементов православной миссионерской деятельности второй половины XIX - начала XX века в Иркутской области // Наследие святителя Иннокентия (Вениаминова) и православная миссионерская деятельность в Сибири, на Дальнем Востоке и сопредельных территориях. Иркутск, 2015. С. 193-198.

12. Тихонов В. В. Перспективы скансенологической практики Иркутской области по актуализации материального наследия православной миссионерской деятельности середины XIX начала XX в. // Православие и дипломатия в странах Азиатско-Тихоокеанского региона. Улан-Удэ, 2020. 192 с.

13. Труды православных миссий Иркутской enархии: т. 1-4. Иркутск: Издание Иркутского комитета православного миссионерского общества, 1884. Тип. Н. Н. Синицина. Т. 2: 1868 1872 гг., 1886, [4]. 632 с.

14. Труды православных миссий Иркутской enapхuи: т. 1-4 гг. Иркутск: Издание Иркутского комитета православного миссионерского общества; Тип. Н. Н. Синицина. Т. 4: 18781883 гг., 1886.678 с.

15. Шерстобоев В. Н. Илимская пашня. T. 1: Пашня Илимского воеводства XVII и начала XVIII в. Иркутск, 1949. 596 с.

16. Якобий А. И. О миссионерском стане в стране Надыма и о возможной поставке христианской миссии в странах русского инородческого Севера. Тобольск: Типография Тобольского Епархиального братства, 1895, [2]. 48 с.

Алтайский государственный педагогический университет (Барнаул, Россия) muzey.obrazovania@yandex.ru

Научный руководитель - О. Н. Труевцева, доктор исторических наук, профессор Алтайский государственный педагогический университет (Барнаул, Россия) truevtseva@yandex.ru

\section{ДЕЯТЕЛЬНОСТЬ МУЗЕЯ ИСТОРИИ ОБРАЗОВАНИЯ ИМ. П. П. КОСТЕНКОВА С 1991 ПО 2021 ГОДЫ}

Аннотация. В статье представлена краткая история становления Музея истории образования им. П. П. Костенкова. Анализируется состав фондового собрания музея и экспозиционно-выставочная работа. Раскрываются возможности музея в сохранении и популяризации наследия педагогического сообщества Алтайского края и Алтайского государственного педагогического университета.

Ключевые слова: музей, фонды, экспозиция, выставка, история образования, педагогический вуз, наследие. 